\title{
DAMPAK KEBIJAKAN EKONOMI TERHADAP PENGHEMATAN DEVISA NEGARA DARI PERDAGANGAN INTERNASIONAL KEDELAI INDONESIA
}

\author{
Dona Wahyuning Laily ${ }^{1)}$, Syafrial ${ }^{2)}$, Heriyanto ${ }^{3)}$ \\ 1) Alumni Mahasiswa Pascasarjana Univ. Brawijaya Malang \\ Emali :
}

\begin{abstract}
ABSTRAK
Tujuan penelitian ini adalah: (1) menganalisis perilaku pasar kedelai domestik yang meliputi penawaran, permintaan, harga domestik, produksi, dan pasar kedelai dunia, (2) menganalisis alternatif kebijakan yang dapat menghemat devisa dari impor kedelai. Simulasi kebijakan yang digunakan dalam penghematan devisa negara adalah (1) peningkatan luas areal panen kedelai di Luar Jawa sebesar $20 \%$. Hal ini berdampak pada penurunan luas areal panen di Jawa sebesar 0,17\%, peningkatan luas areal panen di Luar Jawa sebesar 0,20 \%, pengurangan produktivitas kedelai Jawa sebesar $17,87 \%$, peningkatan produktivitas kedelai Luar Jawa sebesar 39,1\%, penurunan impor kedelai sebesar $0,15 \%$, meningkatkan harga kedelai domestik sebesar $0,19 \%$, meningkatkan permintaan kedelai $7,11 \%$ dan meningkatkan produksi kedelai nasional sebesar $0,70 \%$. (2) menurunkan harga pupuk sebesar $20 \%$ berdampak dengan meningkatnya luas areal panen kedelai di Jawa sebesar $0,16 \%$, meningkatnya luas areal panen kedelai di Luar Jawa sebesar 0,25\%, meningkatkan produktivitas kedelai Jawa sebesar 2,13\%, meningkatkan produktivitas kedelai di Luar Jawa sebesar 0,46\%, menurunkan impor kedelai sebesar $0,11 \%$, meningkatnya harga kedelai sebesar $0,35 \%$, meningkatnya permintaan kedelai sebesar $42,55 \%$ dan meningkatkan produksi kedelai nasional sebesar $0,08 \%$. (3) peningkatan teknologi sebesar $10 \%$ yang akan berdampak pada meningkatnya luas areal panen kedelai Jawa sebesar $0,03 \%$, meningkatkan luas areal kedelai Luar Jawa sebesar 0,04\%, meningkatkan produktivitas kedelai Jawa sebesar 4,14\%, meningkatkan produktivitas kedelai Luar Jawa sebesar $0,91 \%$, menurunkan impor kedelai sebesar 1,00\%, meningkatkan harga kedelai domestik sebesar $0,17 \%$, permintaan kedelai meningkat sebesar $0,07 \%$ dan produksi kedelai nasional meningkat sebesar $1,02 \%$. (4) apresiasi rupiah terhadap US\$ sebesar $50 \%$ akan berdampak pada menurunnya luas areal kedelai Jawa sebesar $0,06 \%$, meningkatnya luas areal kedelai Luar Jawa sebesar $0,18 \%$, menurunnya produktivitas Jawa sebesar $0,09 \%$, meningkatkan produktivitas kedelai Luar Jawa sebesar 3,44\%, menurunkan impor sebesar $0,28 \%$, menurunkan harga kedelai sebesar $0,14 \%$, meningkatkan permintaan kedelai sebesar $0,03 \%$ dan produksi kedelai nasional sebesar $0,06 \%$. (5) meningkatkan tariff impor sebesar $30 \%$ akan berdampak pada meningkatnya luas areal kedelai Jawa sebesar $0,91 \%$, meningkatkan luas areal kedelai Jawa sebesar 1,38\%, meningkatkan produktivitas kedelai Jawa sebesar 11,6\%, meningkatkan produktivitas kedelai Luar Jawa sebesar 25,7\%, menurunkan impor kedelai sebesar $9,15 \%$, meningkatkan harga kedelai domestik sebesar $0,27 \%$, meningkatkan permintaan kedelai domestik sebesar $21,27 \%$ dan meningkatkan produksi nasional sebesar 0,48\%.
\end{abstract}

Kata Kunci : Penghematan, devisa negara, perdagangan internasional, kedelai 


\section{PENDAHULUAN}

Dalam konteks pembangunan nasional, sektor pertanian diposisikan sebagai pendukung dengan kebijaksanaan pangan murah, nilai tukar rupiah rendah (over valued), tingkat suku bunga tinggi, dan pengembangan infrastruktur yang bias kepada sektor industri dan wilayah perkotaan. Kebijaksanaan yang distortif ini tentu sangat memperlemah posisi sektor pertanian dan daya beli sebagian besar konsumen di dalam negeri. Kondisi tersebut menciptakan struktur perekonomian nasional kurang kokoh dan memicu krisis ekonomi, marjinalisasi sektor pertanian, dan tertinggalnya peningkatan pendapatan sebagian besar masyarakat.

Mengingat basis pengembangan ekonomi kerakyatan adalah sektor agribisnis dan agroindustri di pedesaan maka upaya pengembangan ekonomi kerakyatan berbasis pertanian dan ekonomi skala kecil dan menengah perlu didukung dengan kebijaksanaan perdagangan dalam dan luar negeri yang kondusif, disamping kebijaksanaan lainnya yang terkait dengan pengembangan produksi dan produk pertanian khususnya palawija sebagai basis pengembangan sektor agribisnis dan agroindustri.

Kedelai merupakan tanaman utama dalam sistem palawija di Indonesia. Kedelai merupakan sumber pangan masa depan yang penting, karena memiliki manfaat sangat luas. Selain digunakan untuk memenuhi kebutuhan gizi dan pangan manusia, kedelai juga merupakan makanan ternak penting dan bahan mentah bagi industri. Dalam skala perekonomian nasional kedelai merupakan komoditi yang mempunyai nilai strategis, karena mampu mensuplai kebutuhan gizi masyarakat berpenghasilan rendah dan juga merupakan sumber pendapatan bagi petani. Kedelai mempunyai peran dan sumbangan yang besar bagi penyediaan bahan pangan bergizi bagi penduduk dunia, sehingga disebut sebagai "Gold from the soil" (Emas yang muncul dari tanah) dan juga disebut sebagai "The World's Miracle", karena kandungan proteinnya kaya akan asam amino. Kandungan gizi kedelai diperlihatkan pada tabel berikut : 
Tabel 1. Kandungan Gizi dalam Tiap 100 Gram Bahan Kedelai

\begin{tabular}{l|l|l}
\hline \multirow{2}{*}{ Kandungan Gizi } & \multicolumn{2}{|l}{ Banyaknya dalam } \\
\cline { 2 - 3 } & Kedelai Basah & Kedelai Kering \\
\hline Kalori & $286,00 \mathrm{kal}$. & $331,00 \mathrm{kal}$. \\
Protein & $30,20 \mathrm{gr}$ & $34,90 \mathrm{gr}$ \\
Lemak & $15,60 \mathrm{gr}$ & $18,10 \mathrm{gr}$ \\
Karbohidrat & $30,10 \mathrm{gr}$ & $34,80 \mathrm{gr}$ \\
Kalsium & $196,00 \mathrm{mgr}$ & $227,00 \mathrm{mgr}$ \\
Fosfor & $506,00 \mathrm{mgr}$ & $585,00 \mathrm{mgr}$ \\
Zat Besi & $6,90 \mathrm{mgr}$ & $8,00 \mathrm{mgr}$ \\
Vitamin A & $95,00 \mathrm{S.I}$. & $110,00 \mathrm{S.I}$. \\
Vitamin B1 & $0,93 \mathrm{mgr}$ & $1,07 \mathrm{mgr}$ \\
Vitamin C & - & - \\
Air & $20,00 \mathrm{gr}$ & $10,00 \mathrm{gr}$ \\
Bagian yang dapat dimakan & $100,00 \%$ & $100,00 \%$ \\
& & \\
\hline
\end{tabular}

Di Indonesia, produksi kedelai dalam negeri hanya mampu memenuhi konsumsi sekitar 30 persen, sisanya dipenuhi melalui impor. Permintaan impor kedelai selama satu dekade terakhir mengalami peningkatan 6,7 persen per tahun. Impor kedelai diperkirakan akan semakin meningkat di masa mendatang mengingat adanya kemudahan tataniaga impor, yaitu dihapuskannya monopoli Bulog sebagai importir tunggal dan dibebaskannya bea masuk dan pajak pertambahan nilai kedelai. Dengan bea masuk kedelai $0 \%$ dan harga \pm Rp. 1.500,-- Rp. 1.600,$/ \mathrm{kg}$, sangat memukul petani karena biaya produksi kedelai dalam negeri Rp. 2.100,- Rp. 2.200,-/kg. Sebaiknya, apabila pemerintah mengenakan bea masuk kedelai 50\% akan terbentuk harga di pasar sekitar Rp. 2.500,-/kg. Harga komoditas pertanian yang rendah, disincentive bagi peningkatan produksi. Peningkatan impor kedelai yang tajam pada tahun 1999 merupakan salah satu konsekuensi dari perubahan tataniaga tersebut (Sarwanto, 2003).

Penurunan produksi kedelai antara tahun 2000-2001 sebesar 9,27\%. Penurunan produksi ini dikarenakan tidak adanya rangsangan untuk meningkatkan produksi, karena rendahnya harga. Selama 6 kali panen sejak tahun 1998, harga kedelai terus tertekan amat rendah. Tanpa perencanaan yang matang dan langkah-langkah strategis yang konsisten untuk meningkatkan produksi pangan, Indonesia sebagai negara agraris dalam arti mayoritas angkatan kerjanya bekerja di sektor pertanian, akan terus menjadi negara "nett importir" pangan yang sangat besar, yang akan terus semakin membesar, yang pada gilirannya dapat mengancam ketahanan nasional (BPS, 2001). Sehingga cara yang dilakukan untuk mengantisipasi kemungkinan menguatnya kembali rupiah dan persiapan pelaksanaan perdagangan bebas yang lebih luas lagi 
yaitu GATT (General Agreement on Tariff and Trade) tahun 2020 adalah dengan cara memperbesar skala usahatani kedelai, sehingga bisa mencapai produksi kedelai nasional sebesar 2,93 juta ton per tahun seperti yang telah dicanangkan pemerintah agar tercapainya swasembada kedelai yang berkelanjutan, sehingga tidak mengimpor kedelai dalam jumlah yang lebih besar lagi. Dengan demikian, menjelang pelaksanaan kesepakatan GATT (General Agreement on Tariff and Trade) pada tahun 2020 harus sudah mencapai target produksi yang dicanangkan oleh pemerintah (Amaruddin dkk, 2002).

Meningkatnya defisist disebabkan oleh meningkatnya konsumsi perkapita disertai pertumbuhan penduduk, dan menurunnya produksi dalam negeri akibat penurunan areal tanam. Darmadji (2005) menduga bahwa penurunan harga riil kedelai diduga merupakan salah satu faktor utama penyebab turunnya areal tanam kedelai secara drastis. Pada tahun 1992, areal kedelai mencapai 1,87 juta ha turun menjadi sekitar 0,72 juta ha pada tahun 2004. Penurunan harga riil diduga sebagian disebabkan oleh kebijakan liberalisasi impor kedelai dengan tariff $0 \%$, sehingga kedelai impor yang jauh lebih murah menekan harga kedelai di dalam negeri . padahal harga kedelai murah di luar negeri murah bukan karena tingakt efisiensi, akan tetapi karena subsidi dan dukungan yang diberikan oleh negara-negara maju pada petani dan perdagangan mereka.

Rendahnya border price, secara psikologis pasar akan membentuk ekspektasi harga yang cenderung rendah sehingga menurunkan harga ditingkat petani, dan sekaligus merugikan petani. Terjadinya deskrepansi harga tersebut, pelaku pasar cenderung membeli dari importir. Keadaan ini menjadikan produk domestik khususnya kedelai tidak mampu bersaing. Bea masuk impor yang digunakan bersifat ad valorem artinya persentase bea masuk impor yang tetap untuk setiap jumlah komoditi yang diimpor. Kebijakan bea masuk yang diterapkan, tentunya akan berdampak terhadap kesejahteraan (welfare) dari unit-unit ekonomi terkait yaitu kesejahteraan produsen, konsumen dan pemerintah. Dengan demikian, perlu dilakukan suatu kebijakan dalam pengeluaran pemerintah sehingga tidak terjadi pemborosan devisa dan melindungi petani dalam peningkatan kesejahteraan.

\section{TUJUAN PENELITIAN}

1. Menganalisis perilaku pasar kedelai domestik yang meliputi penawaran, permintaan dan harga domestik produksi dan pasar kedelai dunia.

2. Menganalisis alternatif kebijakan yang dapat menghemat devisa dari impor kedelai. 


\section{METODE PENELITIAN}

Penelitian ini merupakan suatu model pendekatan yang bersifat simultan yang melibatkan beberapa kajian agar dapat mewujudkan suatu model simulasi untuk skenario kebijakan ekonomi kedelai. Persamaan struktural yang disusun terbagi atas Blok Dunia yang meliputi persamaan Harga Kedelai Dunia, Impor Kedelai Dunia, Impor Kedelai Indonesia, Ekspor Kedelai Dunia, Ekspor Kedelai Amerika Serikat, dan Blok Domestik yang meliputi persamaan Respon Luas Areal Panen Jawa dan Luar Jawa, Respon Produktifitas Kedelai Jawa dan Luar Jawa, Produksi Kedelai nasional, Impor Kedelai, Harga kedelai di tingkat petani dan harga Impor Kedelai, Permintaan Kedelai. Persamaan struktural pada respon luas araeal panen, produktifitas, dan produksi kedelai selain pada tatanan nasional juga melibatkan Ekonomi kedelai Jawa dan Luar Jawa.

Analisa yang digunakan pada penelitian ini terdiri dari analisis untuk mengetahui faktor-faktor yang mempengaruhi permintaan dan penawaran kedelai dan analisis simulasi historis untuk mengetahui dampak penerapan kebijakan pemerintah terhadap penghematan devisa negara pada kedelai tersebut.

\section{Persamaan struktural tersebut dirancang sebagai berikut:}

1. Luas Areal Kedelai Jawa

$$
\begin{aligned}
& \text { LAKJ }_{\mathrm{t}}=\mathrm{ba}_{0}+\mathrm{ba}_{1} \mathrm{PDKt}_{+}+\mathrm{ba}_{2} \mathrm{PGUNG}_{\mathrm{t}} \\
& +\mathrm{ba}_{3} \mathrm{PBERAS}_{\mathrm{t}}+\mathrm{ba}_{4} \text { PPUKt }+\mathrm{ba}_{5} \mathrm{INV}_{\mathrm{t}}+ \\
& \mathrm{ba}_{6} \mathrm{YKJ}_{\mathrm{t}-1}+\mathrm{ba}_{7} \mathrm{LAKJt}_{-1}+\mathrm{ba}_{8} \mathrm{~T}
\end{aligned}
$$

2. Luas Areal Kedelai Luar Jawa

$$
\begin{aligned}
& \text { LAKLJ }_{t}=b_{0}+b_{1} \text { PDKt }+b_{2} \text { PGUNG }_{t} \\
& +b_{3} \text { PBERAS }_{t}+b_{4} \text { PPUKt }+b_{5} \text { INV }_{t}+ \\
& \text { bb }_{6} \text { YKLJ }_{t-1}+b_{7} \text { LAKLJt }_{-1}+b_{8} \mathrm{~T}
\end{aligned}
$$

3. Produktivitas Kedelai Jawa

$$
\mathrm{YKJ}_{\mathrm{t}}=\mathrm{bc}_{0}+\mathrm{bc}_{1} \mathrm{PDK}_{\mathrm{t}}+\mathrm{bc}_{2} \mathrm{LAKJ}_{\mathrm{t}}
$$

$+\mathrm{bc}_{3} \mathrm{PPUK}_{\mathrm{t}}+\mathrm{bc}_{4} \mathrm{TK}_{\mathrm{t}}+\mathrm{bc}_{5} \mathrm{KDIT}_{\mathrm{t}}+\mathrm{bc}_{6}$

$\mathrm{INV}_{\mathrm{t}}+\mathrm{bc}_{7} \mathrm{YTEBU}_{\mathrm{t}-1}+\mathrm{bc}_{8} \mathrm{~T}$

4. Produktivitas Kedelai Luar Jawa

$\mathrm{YKLJ}_{\mathrm{t}}=\mathrm{bd}_{0}+\mathrm{bd}_{1} \mathrm{PDK}_{\mathrm{t}}+\mathrm{bd}_{2} \mathrm{LAKJ}_{\mathrm{t}}$ + bd $_{3}$ PPUK $_{t}+$ bd $_{4} \mathrm{TK}_{\mathrm{t}}+\mathrm{bd}_{5} \mathrm{KDIT}_{\mathrm{t}}+\mathrm{bd}_{6}$ $\mathrm{INV}_{\mathrm{t}}+\mathrm{bd}_{7} \mathrm{YTEBU}_{\mathrm{t}-1}+\mathrm{bd}_{8} \mathrm{~T}$

5. Produksi Kedelai Jawa

$$
\mathrm{QKJ}_{\mathrm{t}}=\mathrm{LAKJ}_{\mathrm{t}} * \mathrm{YKJ}_{\mathrm{t}}
$$

6. Produksi Kedelai Luar Jawa

$$
\mathrm{QKLJ}_{\mathrm{t}}=\mathrm{LAKLJ}_{\mathrm{t}} * \mathrm{YKLJ}_{\mathrm{t}}
$$

7. Impor Kedelai Indonesia

$$
\begin{gathered}
\mathrm{MKI}_{\mathrm{t}}=\mathrm{be}_{0}+\mathrm{be}_{1} \mathrm{DDLI}_{\mathrm{t}}+\mathrm{be}_{2} \mathrm{PMK}_{\mathrm{t}}+ \\
\mathrm{be}_{3} \mathrm{ERI}_{\mathrm{t}}+\mathrm{be}_{4} \mathrm{GDP}_{\mathrm{t}}+\mathrm{be}_{5} \mathrm{POP}+ \\
\text { be }_{6} \mathrm{STK}_{\mathrm{t}-1}+\mathrm{be}_{7} \mathrm{MLI}_{\mathrm{t}-1}
\end{gathered}
$$

8. Penawaran Komoditas Kedelai di Pasar Domestik

$$
\mathrm{SKDt}=\mathrm{QKN}_{\mathrm{t}}+\mathrm{MKI}_{\mathrm{t}}+\mathrm{STK}_{\mathrm{t}-1}
$$

9. Permintaan Kedelai Nasional

$$
\mathrm{DDLI}_{\mathrm{t}}=\mathrm{bf}_{0}+\mathrm{bf}_{1} \mathrm{PDK}_{\mathrm{t}}+\mathrm{bf}_{2}
$$

$\mathrm{PGUNG}_{\mathrm{t}}+\mathrm{bf}_{3} \mathrm{POPt}+\mathrm{bf}_{4} \mathrm{I}+\mathrm{bf}_{5} \mathrm{DDLI}_{\mathrm{t}-1}$

10. Harga Kedelai di Tingkat Petani

PTLAI $_{t}=b_{0}+b_{1} \mathrm{QKN}_{t}+\operatorname{bg}_{2} \mathrm{PDK}_{\mathrm{t}}+$ $b_{4}$ PGUNG $_{t}+$ bg $_{5}$ PTLAI $_{t-1}$ 
11. Harga Domestik Kedelai

$\mathrm{PDK}_{\mathrm{t}}=\mathrm{bg}_{0}+\mathrm{bg}_{1} \mathrm{ERI}_{\mathrm{t}}+\mathrm{bg}_{2} \mathrm{PWD}_{\mathrm{t}}+$ $\mathrm{bg}_{3} \mathrm{PKUS}_{\mathrm{t}}+\mathrm{bh}_{4} \mathrm{PWK}_{\mathrm{t}}$

12. Harga Dunia Komoditas Kedelai

$\mathrm{PWKt}=\mathrm{bh}_{0}+\mathrm{bh}_{1} \mathrm{XWK}_{\mathrm{t}}+\mathrm{bh}_{2} \mathrm{MWK}_{\mathrm{t}}+$ $\mathrm{bi}_{3} \mathrm{PWK}_{\mathrm{t}-1}$

13. Total Ekspor Dunia Kedelai

$\mathrm{XWK}_{\mathrm{t}}=\mathrm{XUS}_{\mathrm{t}}+\mathrm{XKNL}_{\mathrm{t}}$

14. Ekspor Kedelai Negara Amerika Serikat $\mathrm{XKUS}_{\mathrm{t}}=\mathrm{bi}_{0}+\mathrm{bi}_{1} \mathrm{QKUS}_{\mathrm{t}}+\mathrm{bi}_{2}$ $\mathrm{PWK}_{\mathrm{t}}+\mathrm{bj}_{3} \mathrm{XKUS}_{\mathrm{t}-1}$

15. Total Impor Dunia Kedelai

$\mathrm{MWK}_{\mathrm{t}}=\mathrm{MKI}_{\mathrm{t}}+\mathrm{MKNLt}$

16. Impor Kedelai Negara Indonesia

$\mathrm{MKI}_{\mathrm{t}}=\mathrm{be}_{0}+\mathrm{be}_{1} \mathrm{DDLI}_{\mathrm{t}}+\mathrm{be}_{2} \mathrm{PMK}_{\mathrm{t}}+$

$b_{3} \mathrm{ERI}_{\mathrm{t}}+\mathrm{be}_{4} \mathrm{GDP}_{\mathrm{t}}+\mathrm{be}_{5} \mathrm{POP}+$ $\mathrm{be}_{6} \mathrm{STK}_{\mathrm{t}-1}+\mathrm{bk}_{7} \mathrm{MLI}_{\mathrm{t}-1}+\mathrm{Tr}_{\mathrm{t}}$

dimana :

$\mathrm{LAKJ}_{\mathrm{t}} \quad=$ luas areal kedelai

Jawa(1000ha)

LAKLJt = luas areal kedelai Luar Jawa (1000 ha)

$\mathrm{PDK}_{\mathrm{t}}$

= harga domestik kedelai

$(\mathrm{Rp} / \mathrm{kg})$

PGUNG $_{\mathrm{t}} \quad=$ harga domestik jagung

$(\mathrm{Rp} / \mathrm{kg})$

PPUK $_{\mathrm{t}}=$ harga pupuk $(\mathrm{Rp} / \mathrm{kg})$

$\mathrm{KLS}_{\mathrm{t}} \quad=$ luas konversi lahan

(1000ha)

$\mathrm{T}_{\mathrm{t}} \quad=$ waktu sebagai proksi

tehnologi

$\mathrm{YKJ}_{\mathrm{t}} \quad=$ produktivitas kedelai

kedelai Jawa (1000 ton)
YKJLJ = produktivitas kedelai

Luar Jawa (1000 ton)

KDIT $_{\mathrm{t}}=$ kredit pertanian

$\mathrm{INV}_{\mathrm{t}} \quad=$ investasi di bidang

pertanian

$\mathrm{QKN}_{\mathrm{t}} \quad=$ total produksi kedelai

(1000 ton)

MKI $_{\mathrm{t}}=$ impor kedelai nasional

(1000 ton)

DDLI $_{\mathrm{t}}=$ permintaan domestik

kedelai (1000 ton)

$\mathrm{POP}_{\mathrm{t}} \quad=$ jumlah penduduk

Indonesia

GDPI $_{\mathrm{t}}=$ GDP Indonesia

ERI $\mathrm{t}_{\mathrm{t}}=$ nilai tukar rupiah/dolar

$\mathrm{PWK}_{\mathrm{t}} \quad$ = harga dunia kedelai

$\mathrm{XWK}_{\mathrm{t}} \quad=$ total ekspor kedelai dunia

(1000 ton)

$\mathrm{MWK}_{\mathrm{t}}=$ total impor kedelai dunia

(1000 ton)

XKUS $_{\mathrm{t}}=$ ekspor kedelai oleh

negara USA (1000 ton)

$\mathrm{STK}_{\mathrm{t}-1}=$ stok kedelai tahun lalu

$\operatorname{Tr}_{\mathrm{t}} \quad=$ Tarif yang dikenakan

yaitu $30 \%$

Penelitian ini menggunakan data sekunder time series yang diperoleh dari berbagai instansi terkait serta sumbersumber informasi lainnya, dan karena model ekonomi kedelai yang dibangun merupakan suatu sistem persamaan simultan, maka pendugaan model dilakukan dengan metode 2 SLS (Two stages least square) dan dilanjutkan dengan melakukan 
simulasi kebijakan. Pendugaan model akan dilakukan dengan menggunakan program aplikasi komputer SAS/ETS (Statistical Analysis System/Econometric Time Series). Uji analisis dilakukan dengan menggunakan uji statistik seperti uji F, uji t, uji Durbin-Watson, dan validasi model serta dilanjutkan terhadap simulasi kebijakan yang relevan.

\section{Simulasi Model}

Skenario simulasi yang dilakukan dalam menghemat devisa negara Indonesia adalah:

1. Peningkatan luas areal panen $20 \%$

2. Penurunan harga pupuk $20 \%$

3. Peningkatan teknologi $10 \%$

4. Apresiasi nilai tukar rupiah $50 \%$

5. Peningkatan tariff impor $30 \%$
Simulasi juga dilakukan dengan melakukan kombinasi dari skenario-skenario di atas. Hal ini baik berkaitan dengan adanya exsternal shock maupun berkaitan dengan skenario kebijakannya

\section{HASIL DAN PEMBAHASAN}

Peningkatan Luas Areal Kedelai Di Luar Jawa Sebesar 20\%

Simulasi awal kebijakan yang dilakukan untuk menghemat devisa negara adalah dengan menaikkan luas areal kedelai di Luar Jawa karena selama ini daerah di Luar Jawa kurang mendapat perhatian dari pemerintah. Pada penelitian ini dilakukan analisis simulasi peningkatan luas areal kedelai di Luar Jawa sebesar 20\%. Hasil simulasi kebijakan peningkatan luas areal kedelai di Luar Jawa disajikan pada Tabel 2.

Tabel 2. Hasil Simulasi Peningkatan Luas Areal Kedelai 20\%

\begin{tabular}{l|l|l|l|l|l}
\hline \multirow{2}{*}{ Peubah } & \multirow{2}{*}{ Ssatuan } & Nilai Rata-Rata & Perubahan & \\
\cline { 3 - 6 } & & Simulasi Dasar & Simulasi Skenario & Unit & $\%$ \\
\hline LAKJ & $\mathrm{Ha}$ & 618572.7692 & 725176.2426 & 106603.4734 & $-0,17 \%$ \\
\hline LAKLJ & $\mathrm{Ha}$ & 406783.604 & 492208.1608 & 85424.5568 & $0.20 \%$ \\
\hline YKJ & $\mathrm{Kg} / \mathrm{Ha}$ & 47.77994 & 85472.33678 & 85424.55684 & $-17,87 \%$ \\
\hline YKLJ & $\mathrm{Kg} / \mathrm{Ha}$ & 218.41684 & 85642.97368 & 85424.55684 & $39,1 \%$ \\
\hline MKI & $\mathrm{Kg}$ & 895435.94 & 716348.75 & -143087.19 & $-0.15 \%$ \\
\hline PDK & $\mathrm{Rp} / \mathrm{Kg}$ & 1712.57188 & 2055.086 & 342.51412 & $0.19 \%$ \\
\hline DDLI & $\mathrm{Kg}$ & 26544.519 & 215325.1455 & 188780.6265 & $7.11 \%$ \\
\hline QKN & $\mathrm{Kg}$ & 1155660.48 & 931227.7747 & 815667,2947 & $0.70 \%$ \\
\hline
\end{tabular}

Peningakatan luas areal panen kedelai di Luar Jawa diikuti dengan menurunnya luas areal kedelai di Jawa sebesar 106603,4734 ha $(0,17 \%)$ dan produktivitas Jawa sebesar 85424,55684 $\mathrm{kg} / \mathrm{ha} \quad(17,87 \%)$. Penurunan luas areal kedelai di Jawa ini disebabkan karena banyaknya lahan yang digunakan untuk wilayah industry sehingga luas areal dan produktivitas juga akan semakin menurun 
dari tahun ke tahun. Namun dengan adanya dampak peningkatan luas areal panen kedelai Luar Jawa sebesar 20\% akan meningkatkan tingkat produktivitas sebesar $85424,55684 \mathrm{~kg}(39,10 \%)$. Namun dengan menurunnya produktivitas kedelai di Jawa dan meningkatnya produktivitas kedelai di Luar Jawa tetap akan meningkatkan produksi kedelai nasional sebesar $815667,2947 \mathrm{~kg}(0,70 \%)$.

Peningkatan luas areal di Luar Jawa mendorong untuk menurunkan impor Indonesia sebesar $-143087.19 \mathrm{~kg}(0.15 \%)$ sebagai respon meningkatnya produksi kedelai domestik. Menurunnya impor kedelai nasional akan mendorong peningkatan harga kedelai sebesar $342.51412 / \mathrm{ka}(0.19 \%)$. Peningkatan harga kedelai ini diakibatkan juga dengan peningkatan permintaan kedelai sebesar $188780,6265 \mathrm{~kg}(7,11 \%)$.

\section{Menurunkan Harga Pupuk Sebesar 20\%}

Sebagai langkah berikutnya untuk menghemat negara adalah dengan menurunkan harga pupuk sebesar $20 \%$. Untuk saat ini secara berangsur-angsur pemerintah mengurangi subsidi pupuk walaupun penerapan kebijakan ini masih diperdebatkan. Namun dalam analisis simulasi kebijakan untuk penghematan devisa negara dilakukan analisis untuk penurunan harga pupuk sebesar $20 \%$ dalam arti kata pemerintah masih menerapkan subsidi.

Tabel 3. Hasil Simulasi Penurunan Harga Pupuk Sebesar 20\%

\begin{tabular}{l|l|l|l|l|l}
\hline Peubah & Satuan & \multicolumn{2}{|l|}{ Nilai Rata-Rata } & Perubahan & \\
\cline { 3 - 6 } & & Simulasi Dasar & $\begin{array}{l}\text { Simulasi } \\
\text { Skenario }\end{array}$ & Unit & $\%$ \\
\hline LAKJ & $\mathrm{Ha}$ & 618572.7692 & 618674.5526 & 101.7834 & $0.16 \%$ \\
\hline LAKLJ & $\mathrm{Ha}$ & 406783.604 & 406885.3874 & 101.7834 & $0,25 \%$ \\
\hline YKJ & $\mathrm{Kg} / \mathrm{Ha}$ & 47.77994 & 149.5634 & 101.78346 & $2.13 \%$ \\
\hline YKLJ & $\mathrm{Kg} / \mathrm{Ha}$ & 21841684 & 320.20028 & 101.78344 & $0.46 \%$ \\
\hline MKI & $\mathrm{Kg}$ & 895435.94 & 897334.154 & 1898,21 & $-2.11 \%$ \\
\hline PDK & $\mathrm{Rp} / \mathrm{Kg}$ & 1712.57188 & 1814.35532 & 596.78344 & $0.35 \%$ \\
\hline DDLI & $\mathrm{Kg}$ & 26544.519 & 1156125 & 1129580.481 & $42.55 \%$ \\
\hline QKN & $\mathrm{Kg}$ & 1155660.48 & 1155762.261 & 101.781 & $0.08 \%$ \\
\hline
\end{tabular}

Kebijakan untuk menurunkan harga pupuk sebesar 20\% membawa dampak yang positif untuk luas areal kedelai baik di Jawa sebesar 618674,5526 ha $(0,16 \%)$ maupun di Luar Jawa sebesar 406885.3874 ha $(0,25 \%)$. Sehingga dari peningkatan luas areal panen juga akan meningkatkan produktivitas kedelai Jawa sebesar 149,5634 kg/ha (2.13\%) dan Luar Jawa sebesar 320,20028 kg/ha $(0,46 \%)$. Sehingga akan meningkatkan kedelai nasional sebesar $1155762,261 \mathrm{~kg}(0,08 \%)$. Penurunan harga pupuk sebesar $20 \%$ juga akan berdampak pada penurunan impor 
sebanyak $895334,154 \quad \mathrm{~kg} \quad(2,11 \%)$.

Sehingga permintaan kedelai domestik juga akan meningkat sebesar 1156125 (42,55\%) dan menaikkan harga kedelai nasional sebesar Rp. 596,78344 /kg (0,35\%).

\section{Peningkatan Teknologi Sebesar 10\%}

Tingkat penggunaan teknologi yang lebih tinggi mampu meningkatkan produksi kedelai, walaupun dalam presentase yang lebih kecil dibandingkan dengan peningkatan luas areal kedelai dalam jumlah yang sama. Kenaikan jumlah produksi sebesar $1155859,68 \mathrm{~kg}(1,01 \%)$ yang dihasilkan akan menurunkan impor kedelai sebesar $885342,1376 \mathrm{~kg}(1,52 \%)$ dan meningkatkan harga sebesar Rp.1911,772 /kg (0,17\%), dimana kenaikan harga kedelai ini akan mempengaruhi jumlah permintaan kedelai

Tabel 4. Hasil Simulasi Peningkatan Teknologi 10\%

\begin{tabular}{l|l|l|l|l|l}
\hline Peubah & \multirow{2}{*}{ Satuan } & Nilai Rata-Rata & Perubahan \\
\cline { 3 - 6 } & & Simulasi Dasar & Simulasi Skenario & Unit & $\%$ \\
\hline LAKJ & $\mathrm{Ha}$ & 618572.7692 & 618771.9692 & 199.2 & $0.03 \%$ \\
\hline LAKLJ & $\mathrm{Ha}$ & 406783.604 & 406982.804 & 199.2 & $0.04 \%$ \\
\hline YKJ & $\mathrm{Kg} / \mathrm{Ha}$ & 47.77994 & 246.97994 & 199.2 & $4.16 \%$ \\
\hline YKLJ & $\mathrm{Kg} / \mathrm{Ha}$ & 218.41684 & 417.61684 & 199.2 & $0,91 \%$ \\
\hline MKI & $\mathrm{Kg}$ & 895435.94 & 885342.1376 & -10093.8024 & $-1.52 \%$ \\
\hline PDK & $\mathrm{Rp} / \mathrm{Kg}$ & 1712.57188 & 1911.772 & 199.150 & $0.17 \%$ \\
\hline DDLI & $\mathrm{Kg}$ & 26544.519 & 26743.72 & 199.01 & $0.07 \%$ \\
\hline QKN & $\mathrm{Kg}$ & 1155660.48 & 1155859.68 & 199.2 & $1.01 \%$ \\
\hline
\end{tabular}

Perbandingan untuk produktivitas Jawa sebesar 246,97994 kg/ha $(4,16 \%)$ dan Luar Jawa sebesar 417,61684 kg/ha $(0,91 \%)$ mempunyai perbedaan yang cukup jauh untuk peningkatan teknologi. Hal ini disebabkan karena saaat ini teknologi masih banyak diterapkan oleh petani Jawa yang mau menerima perubahan sedangkan petani Luar Jawa masih menggunakan cara yang konvensional dalam melakukan bercocok tanam.

\section{Apresiasi Nilai Tukar Rupiah Terhadap} US\$ Sebesar 50\%.

Sejak tahun 1998, kondisi ekonomi dunia memburuk dan berimbas pada perekonomian Indonesia. Terjadi peningkatan nilai tukar rupiah terhadap US\$ yang cukup tentu saja akan membuat pemerintah mengeluarkan devisa negara yang tinggi untuk membeli kedelai impor. Sehingga pada bagian ini disimulasikan dengan menguatnya nilai tukar rupiah nilai tukar rupiah sebesar 50\%. Hasil simulasi akan disajikan pada Tabel 27.

Apresiasi nilai tukar rupiah sebesar 50\% menurunkan jumlah kedelai impor sebesar $916188,1696 \mathrm{~kg}(2,43 \%)$ dan menurunkan harga kedelai di pasar domestik sebesar Rp. 1464,80388 /kg $(0,14 \%)$. Penurunan harga kedelai domestik 
ini berdampak pada menurunnya luas areal kedelai di Jawa sebesar 614325,0012 ha $(0,06 \%)$ dan produktivitas di Jawa sebesar 43,01194 kg/ha (0,09\%). Hal ini dikarenakan di Jawa dengan menguatnya nilai tukar rupiah maka akan mengakibatkan peralihan luas areal kedelai untuk kebutuhan industri atau komersial sebagai investasi. Namun areal Luar Jawa mengalami peningakatan sebesar 407535,836 ha $(0,18 \%)$ dan meningkatkan produktivitas sebesar $970,84884 \mathrm{~kg} / \mathrm{ha}$ $(3,44 \%)$

Tabel 5. Hasil Simulasi Apresiasi Nilai Tukar Rupiah Terhadap US\$

\begin{tabular}{l|l|l|l|l|l}
\hline Peubah & \multirow{2}{*}{ Satuan } & Nilai Rata-Rata & Perubahan & \\
\cline { 3 - 6 } & & Simulasi Dasar & Simulasi Skenario & Unit & $\%$ \\
\hline LAKJ & $\mathrm{Ha}$ & 618572.7692 & 614325.0012 & -4247.768 & $-0.06 \%$ \\
\hline LAKLJ & $\mathrm{Ha}$ & 406783.604 & 407535.836 & 752.235 & $0.18 \%$ \\
\hline YKJ & $\mathrm{Kg} / \mathrm{Ha}$ & 47.77994 & 43.01194 & -4.768 & $-0.09 \%$ \\
\hline YKLJ & $\mathrm{Kg} / \mathrm{Ha}$ & 218.41684 & 970.84884 & 752.432 & $3.44 \%$ \\
\hline MKI & $\mathrm{Kg}$ & 895435.94 & 916188.1696 & 20752.2296 & $-2.43 \%$ \\
\hline PDK & $\mathrm{Rp} / \mathrm{Kg}$ & 1712.57188 & 1464.80388 & -247.768 & $-0.14 \%$ \\
\hline DDLI & $\mathrm{Kg}$ & 26544.519 & 27296.7508 & 752.2318 & $0.03 \%$ \\
\hline QKN & $\mathrm{Kg}$ & 1155660.48 & 1156412.709 & 752.229 & $0.06 \%$ \\
\hline
\end{tabular}

Respon penurunan impor lebih besar dari respon peningkatan produksi sehingga akan mengakibatkan peningkatan permintaan kedelai sebesar 27296,7508 kg $(0,03 \%)$. Hal ini disebabkan karena kebutuhan konsumsi masyarakat Indonesia yang semakin meningkat dan membaiknya perekonomian yang labih baik juga.

\section{Meningkatkan Tarif Impor Sebesar 30\%}

Pada era perdagangan bebas, kebijakan perdagangan antar negara dipengaruhi berbagai perjanjian internasional, seperti Putaran Uruguay, AFTA, APEC dan WTO. Perjanjian tersebut mengatur tentang penghapusan kebijakan non tariff (kuota) dan menurunkan tariff impor. Pada periode tahun 1969-1982, tariff impor sebesar 30\% menurun menjadi $10 \%$ pada periode tahun
1983-1993 dan menurun lagi menjadi 5\% pada periode sesudahnya. Pada bagian ini disimulasikan untuk kembali meningkatkan tariff impor sebesar 30\% untuk menghemat devisa negara. Hasil simulasi disajikan pada Tabel 27.

Meningkatnya tariff impor berarti meningkatkan harga kedelai impor di Indonesia, karena terdapat peningkatan biaya yang ditanggung oleh importer untuk setiap kilogram kedelai yang di impor. Semakin tinggi tariff impor maka semakin tinggi harga kedelai impor di pasar domestik sehingga harga impor dapat bersaing dengan harga kedelai domestik. Hal ini mengakibatkan jumlah impor kedelai mengalami penurunan sebesar $760069,37 \mathrm{~kg}(9,15 \%)$. Dengan adanya pembatasan kedelai impor karena 
meningkatnya pajak impor maka importer lebih membatasi kedelai impor masuk ke pasar domestik dan lebih menekankan kedelai domestik di pasaran. Sehingga dengan meningkatnya permintaan sebesar $591177,95 \mathrm{~kg}(21,27 \%)$ akan menaikkan harga kedelai domestik sebesar Rp.2177,95 $/ \mathrm{kg}(0,27 \%)$.

Tabel 6. Hasil Simulasi Meningkatnya Tariff Impor Sebesar 30\%

\begin{tabular}{|c|c|c|c|c|c|}
\hline \multirow[t]{2}{*}{ Peubah } & \multirow[t]{2}{*}{ Satuan } & \multicolumn{2}{|l|}{ Nilai Rata-Rata } & \multicolumn{2}{|l|}{ Perubahan } \\
\hline & & Simulasi Dasar & Simulasi Skenario & Unit & $\%$ \\
\hline LAKJ & $\mathrm{Ha}$ & 618572.7692 & 1183206.20 & 564633.4308 & $0.91 \%$ \\
\hline LAKLJ & $\mathrm{Ha}$ & 406783.604 & 971417.03 & 564633.426 & $1.38 \%$ \\
\hline YKJ & $\mathrm{Kg} / \mathrm{Ha}$ & 47.77994 & 554681.21 & 554633.4301 & $11.6 \%$ \\
\hline YKLJ & $\mathrm{Kg} / \mathrm{Ha}$ & 218.41684 & 564851.85 & 56263.43316 & $25.7 \%$ \\
\hline MKI & $\mathrm{Kg}$ & 895435.94 & 760069.37 & -135366.57 & $-9.15 \%$ \\
\hline PDK & $\mathrm{Rp} / \mathrm{Kg}$ & 1712.57188 & 2177.95 & 465.37812 & $0.27 \%$ \\
\hline DDLI & $\mathrm{Kg}$ & 26544.519 & 591177.9 & 564633.431 & 21.27 \\
\hline QKN & $\mathrm{Kg}$ & 1155660.48 & 1720293.91 & 564633.43 & $0.48 \%$ \\
\hline
\end{tabular}

Peningkatan harga kedelai domestik ini akan direspon dengan meningkatnya luas areal kedelai baik di Jawa sebesar 1183206,20 ha $(0,91 \%)$ dan Luar Jawa sebesar 971417,03 ha $(1,38 \%)$ dan mampu meningkatkan produkstivitas di Jawa $554681,21 \mathrm{~kg} / \mathrm{ha}(11,6 \%)$ dan Luar Jawa sebesar 564851,85 kg/ha (25,7\%). Sehingga secara keseluruhan akan meningkatkan produksi kedelai nasional sebesar $1720293,91 \mathrm{~kg}(0,48 \%)$.

\section{Kebijakan Ekonomi Terhadap}

\section{Penghematan Devisa Negara}

Dalam rangka perumusan kebijakan masa yang akan datang, maka disimulasikan berbagai kebijakan alternatif dalam rangka penghematan negara, dimana scenario yang digunakan dalam simulasi ekonomi ini didasarkan apa yang telah dihasilkan pada simulasi ekonomi.
Berdasarkan

Departemen

Perdagangan bahwa saat ini devisa negara yang digunakan pemerintah untuk nilai impor kedelai adalah sebesar US\$ 332,082 juta (3,3 triliyun rupiah) selama satu tahun. Dana yang memboroskan devisa negara itu sebenarnya bisa dimanfaatkan untuk pengembangan industri pertanian dalam negeri sehingga Indonesia bisa memproduksi sendiri dan tidak bergantung pada negeri lain. Bahkan, tidak tertutup kemungkinan Indonesia sebagai negara agraris besar bisa mengekspor komoditas pangan yang justru mendatangkan devisa. Dengan demikian, pemerintah tidak perlu terlalu mengandalkan utang luar negeri untuk membiayai pembangunan (Kompas, 2008). Maka selayaknya pemerintah dapat berfikir secara serius untuk dapat menekan keuangan negara untuk dapat menghemat devisa. 
Tabel 7. Hasil Perhitungan Perubahan Penghematan Devisa Negara Dari Berbagai Skenario Kebijakan Ekonomi Stelah Adanya Simulasi

\begin{tabular}{l|l|l|l}
\hline No. & Nama Simulasi & Nilai Devisa (Dalam juta) & Perubahan Devisa (\%) \\
\hline 1. & Sim I & Rp. 2.789 .267 .203 & $3.69 \%$ \\
\hline 2. & Sim II & Rp. 7.581.532.195 & $6.41 \%$ \\
\hline 3. & Sim III & Rp. 781.327 .000 & $-6.81 \%$ \\
\hline 4. & Sim IV & Rp. 4.674 .961 .000 & $4.65 \%$ \\
\hline 5. & Sim V & Rp. 8.993 .640 .000 & $9.84 \%$ \\
\hline
\end{tabular}

Berdasarkan pada tabel diatas dapat dijelaskan sebagai berikut bahwa terdapat 5 simulasi kebijakan yang dapat digunakan dalam penghematan negara yaitu pada simulasi I, II, V, danV. Sedangkan pada simulasi III yaitu kebijakan peningkatan teknologi belum berperan dalam menghemat negara. Selama ini pemerintah banyak menciptakan teknologi untuk peningkatan produksi kedelai. Namun dalam penerapannya berkurang. Hal ini disebabkan karena kurangnya penggunaan teknologi dan pemanfaatan teknologi pada petani serta kurangnya pemerintah dalam mengenalkan teknologi kepada masyarakat terutama masyarakat di Luar Jawa. Kurangnya informasi dan kurangnya kepercayaan masyarakat terhadap teknologi juga menghambat penyerapan teknologi. Karena kebanyak petani di Luar Jawa lebih memilih bertanam konvensional dalam berusahatani kedelai.

Dari data diatas pula dapat diketahui bahwa dengan adanya penerapan berbagai kebijakan yang telah disebutkan maka pemerintah dapat menghemat devisa sebesar Rp. 24.920.727.398 selama satu tahun. Selain mampu mengurangi impor, potensi negara agraris seharusnya membuat Indonesia mampu mencukupi kebutuhan pangan, sekaligus mengurangi, bahkan menyetop impor kedelai.

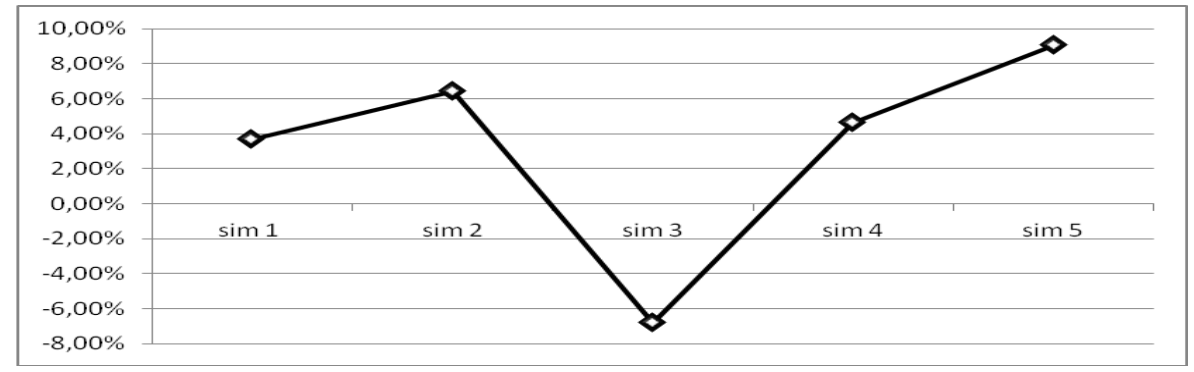

Gambar 33. Perubahan Devisa Dalam Penghematan Devisa 
Berdasarkan

perubahan

penghematan devisa negara, kebijakan pada Sim II dan Sim V dapat menghemat devisa paling besar. Pada simulasi penurunan harga pupuk diharapkan akan terjadi peningkatan hasil produksi kedelai sehingga impor kedelai dapat ditekan secara maksimal. Dari devisa ini diharapkan pada masa perekonomian yang akan datang pemerintah lebih menekankan peningkatan pendapatan pada masyarakat yang signifikan tiap tahun. Karena dari pendapatan yang tinggi ini kemakmuran dan kesejahteraan masyarakat akan lebih tercapai. Dengan meningkatnya permintaan pendapatan maka konsumsi masyarakat akan bahan dasar kedelai juga akan meningkat dan meningkatkan produksi nasional. Sedangkan untuk peningkatan tariff impor juga bisa menghemat devisa negara yang besar. Hal ini karena selama ini dalam pelaksanaannya impor kedelai dapat menurunkan tingkat produksi kedelai domestik. Adanya tariff impor $30 \%$, maka pemerintah dapat menghemat devisa negara sebanyak $9.14 \%$.

\section{KESIMPULAN}

Berdasarkan hasil penelitian ini dapat dikemukakan beberapa kesimpulan:

1. Model ekonomi kedelai hasil penelitian ini layak digunakan untuk mengevaluasi berbagai kebijakan penghematan devisa negara pada perdaganga kedelai pada periode 1980 -
2005. Model terdiri dari dari Sembilan persamaan struktural dan 5 persamaan identitas. Validasi model ditunjukkan bahwa hasil analisis memenuhi kriteria uji dengan nilai US rata-rata dibawah 0,1 . Nilai UC rata-rata lebih dari 0,8 serta nilai $\mathrm{R}^{2}$ rata-rata lebih dari 0,8147 dan sangat layak digunakan untuk simulasi kebijakan dalam menghemat devisa negara.

2. Perilaku ekonomi kedelai dikemukakan sebagai berikut:

2.1. Areal panen kedelai Jawa dipengaruhi secara nyata dan bertanda positif oleh harga kedelai domestik, harga beras, produktivitas kedelai Jawa tahun sebelumnya, luas areal panen kedelai tahun sebelumya dan tren waktu. Sedangkan harga pupuk berpengaruh tidak nyata dan negatif.

2.2. Areal panen kedelai Luar Jawa dipengaruhi secara nyata dan bertanda positif oleh harga kedelai domestik, investasi, luas areal kedelai Luar Jawa tahun sebelumnya, dan trend waktu. sedangkan dipengaruhi tidak nyata dan bertanda negatif oleh harga pupuk.

2.3. Produktivitas kedelai Jawa dipengaruhi nyata dan bertanda positif oleh harga domestik kedelai, investasi, dan trend waktu. 
sedangkan luas areal kedelai Jawa, harga pupuk, dan kredit pertanian berpengaruh tidak nyata dan negatif.

2.4. Produktivitas kedelai Luar Jawa dipengaruhi secara nyata dan positif oleh investasi dan trend waktu. sedangkan harga kedelai domestik, kredit pertanian, dan produktivitas tebu tahun sebelumnya berpengaruh tidak nyata dan negatif.

2.5. Permintaan kedelai dipengaruhi secara nyata dan bertanda positif adalah populasi, pendapatan dan permintaan kedelai tahun sebelumnya. Sedangkan harga kedelai domestik berpengaruh tidak nyata dan negatif.

2.6. Harga kedelai di tingkat petani dipengaruhi nyata dan bertanda positif oleh produksi kedelai nasional, harga jagung dan harga kedelai petani tahun sebelumnya.

2.7. Harga kedelai di tingkat domestik dipengaruhi secara nyata dan bertanda positif oleh nilai tukar rupiah, dan harga kedelai dunia, dan harga kedelai USA. Sedangkan harga kedelai dunia tahun sebelumnya berpengaruh negative dan tidak nyata.

2.8. Harga kedelai di tingkat dunia dipengaruhi secara nyata dan bertanda positif oleh ekspor dunia kedelai dan harga dunia kedelai tahun sebelumnya. Sedangkan impor dunia kedelai berpengaruh tidak nyata dan negatif.

3. Hasil simulasi menunjukkan bahwa kebijakan yang dapat menghemat / meningkatkan devisa negara adalah: (1) meningkatkan luas areal panen kedelai di Luar Jawa sebesar 20 persen, (2) menurunkan harga pupuk sebesar 20 persen, (3) meningkatkan teknologi sebesar 10 persen, (4) apresiasi nilai tukar rupiah terhadap US\$ sebesar $50 \%$, (5) meningkatkan tariff impor sebesar 30 persen.

4. Analisis simulasi kebijakan historis menunjukkan dampak kebijakan terhadap permintaan dan penawaran kedelai sebagai berikut:

\section{1.kebijakan peningkatan} produktivitas kedelai, peningkatan pendapatan per kapita, depresiasi rupiah mendorong petani memperluas areal panen kedelai sehingga produksi kedelai meningkat dan impor menurun.

$$
\begin{aligned}
& \text { 4.2. kebijakan penurunan subsidi } \\
& \text { pupuk, penurunan tariff impor } \\
& \text { kedelai mendorong peningkatan } \\
& \text { impor kedelai. }
\end{aligned}
$$

5. 5. Dalam simulasi I, II, III, IV, V, dan VI, hanya pada simulasi yang ke tiga yaitu peningkatan teknologi 10 persen terjadi pemborosan devisa sesesar 6,81 persen karena pemerintah banyak 
mengupayakan teknologi yang tepat guna seperti pengadaan bibit unggul, alat dan mesin pertanian sedangkan petani belum banyak menyerap adanya teknologi tersebut. Sehingga pemerintah banyak mengeluarkan banyak devisa untuk menyediakan teknologi tersebut.

\section{DAFTAR PUSTAKA}

Amang, B, Sawit, M.H, Rachman, A. 1996. Ekonomi Kedelai Di Indonesia. IPB Press. Bogor

Amaruddin, Masyhuri dan Sutrilah. 2002. Analisis Keunggulan Komparatif dan Tingkat Proteksi Efektif pada Komoditas Kedelai Di Pulau Jawa. Agrosains Volume 15 No. 2. Mei 2002.

Biro Pusat Statistik. 2001. Data Statistik Indonesia BPS. Jakarta

Brandson, W.H. and J.M. Litvatch. 1981. Macroeconomics. $2^{\text {nd }}$ Edition. Harper and Row Publisher. New York.

Dahoelat, D.N.R. 2003. Analisis Simulasi Pengaruh Kebijakan Pemerintah Terhadap Harga Beras Di Indonesia. Tesis Universitas Brawijaya. Malang.

Dian, T.D. 2003. 4 Produk Pertanian Diusulkan Diproteksi. Berita Bisnis. 28 Mei 2003

Dibyo Prabowo dan Sonia Wardoyo. 2004. AFTA Suatu Pengantar. Edisi 2004/2005. BPFE Yogyakarta.
Direktorat Gizi Depkes R.I. 1981. Daftar Komposisi Bahan Makanan. Bharatara Karya Aksara - Jakarta.

Erwidodo. 1997. Implikasi dan dampak Putaran Uruguay pada Sektor Pertanian Di Indonesia. AgroEkonomika. Nomor 2 Tahun XXVII Oktober 1997. PERHEPI. Jakarta.

FAO. "FAOSTAT Databese Collections." Web page, [accesed 2008]. Available at http://apps.fao.org/cgi-bin/nphdb.pl?subset-agriculture.

Ferris, J.N. 1998. Agricultural Prices and Commodity Market Analysis. McGraw Hill Company. USA.

Gallagher, P. 1987. U.S. soybean yields: estimation and forecasting with nonsymmetric disturbances. American Agricultural Economics, Volume 69, Number 4, November, 796-803.

Gujarati, D.N. 1995. Basic Econometrics. McGraw-Hill Book Co. Singapura.

Hadipurnomo, T. 2000. Dampak Kebijakan Produksi dan Perdagangan Terhadap Penawaran dan Permintaan Kedelai di Indonesia. Tesis IPB.

Hafsah Jafar. 2003. Deptan Kecewa Belum Ditetapkannya BM Kedelai. AgroIndonesia. PT. Cakrawala Pengembangan Agrosejahtera. Jakarta.

2004. Deptan Minta Perlambatan Penurunan Tarif Bea Masuk Kedelai dan Jagung. 
Bali Post. 28 April 2004. Jakarta.

Hapsari, T.D. 2004. Dampak Kebijakan Pemerintah Terhadap Permintaan dan Penawaran Komoditas Kedelai Di Indonesia (Suatu Analisis Simulasi Historis). Tesis Universitas Brawijaya,. Malang.

Henderson, J.M, and Quant, R, 1980, Microeconomic Theory, Third Edition, McGraw-Hill International Book Company, Singapore.

Hira Jhamtani. 2000. Artikel Seputar Kekayaan Intelektual. Kompas. 12 Mei 2000.

Hutapea, J dan Mashar, A.Z. 2004. Ketahanan Pangan dan Teknologi Produktivitas Menuju Kemandirian Pertanian Indonesia. Hasil Penelitian. Departemen Tenaga Kerja dan Transmigrasi. Jakarta.

Intriligator, M.D. 1978. Econometric Model : Techniques and Applications. Prentice Hall. New Delhi.

Jamilah. 2005. Pengaruh Kebijakan Tarif Impor Terhadap Ekonomi Kedelai Di Indonesia. Tesis Universitas Brawijaya. Malang.

Kiptiyah, S.M. 1994. Implikasi Kebijaksanaan Harga Gula Terhadap Kesejahteraan dan Pendapatan Produsen, Konsumen, dan Pemerintah dalam Usaha Mencapai Swasembada Gula. Jurnal Universitas Brawijaya Vol. 6 No 1 Malang.

Koutsoyiannis, A. 1982. Modern Microeconomics, Second Edition, The MacMillan Press. Hongkong.

Labys, W.C. 1973. Dynamic commodity models: specification, estimation, and simulation. D.C. Heath and Company, Lexington Massachusetts, Toronto-London.

Manwan, Sumarno, A.S. Karama, dan A.M. Fagi. 1990. Teknologi Peningkatan Produksi Kedelai Di Indonesia. Laporan Khusus Pus/02/89; Bogor.

Manwan, I dan Sumarno. 1996. Perkembangan dan Penyebaran Kedelai.. Ekonomi Kedelai Di Indonesia. IPB Press. Jakarta.

Mathari Rusdi, Winarno Bajo, Sukandar Priyanto dan Prakosa Kelik. 2005. Proteksi Untuk Kesejahteraan Petani. Rubrik Politik. 23Maret 2005. Jakarta.

Muchlizar. 2004. Tahun 2008 Indonesia Tidak Perlu Impor Kedelai. PoultryIndonesia.Com. 17 Agustus 2004.

Muhazir. 2004. Harga Kedelai Naik, Petani Untung. Suara Merdeka. 16 Agustus 2004. 